\title{
Information Behavior in Crisis Situations
}

\author{
Monika Krakowska \\ ORCID 0000-0002-2724-9880 \\ Institute of Information Studies, \\ Faculty of Management and Social Communication \\ Jagiellonian University in Krakow, Poland
}

\begin{abstract}
Purpose/Thesis: The article presents the scholarship on information behavior during crises, conflicts and disasters. It includes theoretical reflection on the subject of identifying heterogeneous information activities and attempts to define and characterize various crisis situations.

Approach/Methods: The presented research employs qualitative approach, and methods/techniques: scoping literature review, conceptual analysis and thematic analysis. The data sample comprised selected, representative publications from 2001-2020.

Results and Conclusion: Research on information behavior in various crisis situations is an important research area of information science. However, it remains understudied; the field should be expanded to account for multifaceted issues of individual and collective informational behavior in contemporary crisis situations and disasters.

Originality/Value: The article is the first theoretical and conceptual analysis of information behavior in crisis situations. The article discusses various types of crises and information activities undertaken in crisis situations to develop a theoretical and practical foundation for future research on information behavior.
\end{abstract}

Keywords

Crisis. Crisis situation. Disaster. Information behavior. Qualitative analysis. Qualitative content analysis.

Received: 8 November 2020. Reviewed: 2 December 2020. Revised: 8 December 2020.

Accepted: 18 December 2020.

\section{Introduction}

Various catastrophes, such as crises, conflicts, natural disasters, accidents, terrorist attacks, various problems of social, economic, political and psychological nature are an inevitable part of human life. They have an impact not only on the environment in which individuals function, but also on their physiological, affective and social well-being. Crisis situations drastically change the context of all individual and collective actions, including information activities. Crises and disasters disrupt our routines and, therefore, they condition our information behaviors, which become more dynamic, sometimes even chaotic, while they remain focused on eliminating the problem, in order to persevere through and eventually to overcome the crisis. Often, due to the sudden nature of a crisis or a catastrophe, information behavior becomes extremely varied, subject to many factors. It is usually anxious, determined by emotions, and time-sensitive (Allen, 2011). A crisis is an experience, but also an event or situation that is usually unexpected, 
incidental, unacceptable and unprecedented, often impossible to control. In addition, it has a significant impact on social beliefs and may reduce trust; it may provoke dangerous reactions, such as riots and wars, that threaten life of the community (Rahmi et al., 2018). Crisis may also be a kind of stimulus, triggering specific information behaviors (Miller, 2011; Pisani et al., 2016). The crisis situation is the context for all possible activity, including solutions (Pang, 2014). A catastrophe is often defined by a disruptive impact it has on entire communities, countries, and the natural environment. This phenomenon is incredibly dangerous: it may even cause a fatal disturbance of social order and harmony, and a feeling of helplessness in the individuals who lose the sense of security as a result of damage to property, loss of health, or economic and environmental losses (Rahmi et al., 2018). Undoubtedly, crisis situations and disasters affect human information behavior. In a crisis situation, habits often change, as individuals adjust their active and passive gathering information processes, information seeking and searching, information use or dissemination activities. Research on behavior in a crisis situation in information science accounts for many aspects, for example finding information, responding to information, as well as the use of new technologies and social media to disseminate information, social and emotional responses to a specific event, information management in crisis situations, evaluation of various activities carried out in response to violence, terrorist attacks or natural disasters, such as hurricanes (Lopatovska \& Smiley, 2014) or floods (Kellens et al., 2011).

In order to show the current state of knowledge on information behavior in crisis situations, the present study examines key issues related to this area. The research has two aims. Firstly, to establish and analyze the state of scholarship on information behavior in crisis situations or in disasters. This was achieved by an analysis of diverse articles. The second aim was to develop, define and categorize various crisis situations in order to establish a theoretical foundation for further research. Conceptual analysis was therefore carried out to identify the most important trends in the information science research on crisis situations. It accounted for factors that determine information behavior and its features. The study adopts a broad understanding of information behavior, which is interpreted as all activities relating to information carried out in a specific reality (Wilson, 2013). These activities may be conscious or unconscious, active or passive, intentional or unexpected, and are undertaken in a specific, multi-dimensional context (Cisek, 2017; Wilson, 2013). Information behavior accounts for the ways in which people need, gather, manage, use, disseminate and respond to information (Fisher \& Julien, 2009; Krakowska, 2016) in specific contexts, which comprise action, time and situation, including also geographical space, and affective, social and cognitive dimensions in which sense is constructed (Case \& Given, 2016; Krakowska, 2016; Savolainen, 2005; Vakkari, 1997).

The research presented here focuses on the recognition of various crises, which include both natural and human disasters. These circumstances shape human information activities. Therefore, understanding, interpreting, and precise analysis of information behaviors and factors introduced by crisis situations is a crucial aspect of information science. 


\section{Conceptual framework}

\subsection{Crisis definition and types}

There is no uniform definition of a "crisis" (Shaluf et al., 2003; Perry, 2007); various terms are used to describe this phenomenon, such as crisis or catastrophe, critical incident, or crisis moment (Shaw, 2010). The term covers a wide range of meanings and its definition depends on the discipline. It is defined, similarly to the term disaster, as a concept, phenomenon or a research area. In philosophy, it suggests a breach, or a separation. It indicates finality, a certain turn, but also an understanding of the situation and its conditions (Tangija, 2014). It is therefore a breakthrough for the individual. Crisis is thus understood as a determinant of cognitive processes, which allows the individual to recognize the cause of the situation, enabling them to grasp and evaluate the phenomenon and its context, and gain insight that may cause qualitative changes in human life. It allows the individual to interpret and understand certain actions. It can reveal the weakness or non-adaptability of an object, subject or situation. It also implies that the phenomenon unsettles a structure or disturbs an equilibrium because of its suddenness and traumatizing quality. It is a subjective challenge, but it is also associated with negative emotions that trigger anxiety (Bundy et al., 2016). Nevertheless, crisis has some positive features. It is a temporary phenomenon that enables transformation and may result in the emergence of a new mode of activity (Tangija, 2014). Both internal causes, inherent to any phenomenon, process, and the external factors that affect the crisis situation, shape human activity and its environment. A crisis is often a turning point in an unfolding sequence of events and actions (Keown-McMullan, 1997). As a state of disorder, experienced as a difficulty, crisis may disturb the functioning of individuals and whole groups. It causes internal imbalance, emotional disturbance, and a sense of instability that always follows an unexpected event. Often it has a negative impact on individuals' mental well-being due to the lack of appropriate remedial measures, as well as their inability to react properly or to use the various previously available resources, which have thus far regulated the individual's life. Any specific crisis requires meaningful, constructive solutions intending to change the difficult conditions, state and eliminate the effects of any conflict, disaster, accident or other form of catastrophe. Moreover, crisis may be a result of human activities, such as economic and political operations. It may also be a consequence of natural disasters and human fault. As an unusual event, natural or man-made, or resulting from a failure of technological systems, crisis temporarily overwhelms the society's capacity for rehabilitation, as well as saving and preserving the natural environment. It causes enormous damage, economic loss, disruption, injury and possible loss of life. Generally, crises could be divided according to their causes into man-made or technological and natural. There are also hybrid disasters resulting from both human error and natural forces (Shaluf, 2007). Crises can be grouped into four types: (a) conventional (predictable - including those resulting from technological failures, e.g. power outages), (b) unexpected (unpredictable, for which no response has been prepared in advance, e.g. an explosion), (c) unsolvable (rather predictable, but difficult to control, resulting from faulty crisis management systems, e.g. a nuclear power plant accident), and (d) basic (the most dangerous, intense and long-lasting, e.g. a terrorist attack) (Gundel, 2005). Crises can be also classified as 
community crises and non-community crises, which include transportation accidents, such as railway or airplane crashes. The community crises are further divided into non-industrial crises, industrial crises, which include socio-technical disasters, such as structural collapses, fires, explosions, and, finally, natural crises, which include natural disasters, e.g. tornados, earthquakes. Non-industrial crises are divided according to conflict type, e.g. political crises, which is further divided into internal and external. Non-conflict crises include social crises and economic crises, further divided into non-financial crises, caused by faults of the organization, miscalculation of business risk, or poor decision-making (Shaluf et al., 2003). We may also distinguish personal crises, which are influenced by many factors, relating to health as well as social, mental and economic (e.g. domestic violence, migration, crimes). Crisis may be understood as an event, a circumstance, a sudden incident, a disruption, but also as a process (Wooten \& James, 2008). It refers to any situation with an emotional charge, characterized by complexity and uncertainty (Maitland \& Sammartino, 2015). Cognitive processes, accumulation of knowledge, skills and experience are crucial to understand a crisis and to respond with appropriate and strategic and decisions (Combe et al., 2012; Samdanis \& Lee, 2019). Crisis, when defined as a process, is characterized by an accumulation of problems, variance across different stages, and cyclicality. Often it is not a sudden incident, but time pressure and the dynamics of the reaction that have a significant impact on the activities undertaken in all stages of the crisis (Bakker \& Sheperd, 2017; Meredino \& Sarens, 2020). In economy, it is a multistage process, the stages include detection, preparation, containment and control, as well as business recovery, learning and reflection (Wooten \& James, 2008). Crises result from internal and external episodes, such as inappropriate information behaviors, interpersonal conflicts, and macro-environment conditions (Meredino \& Sarens, 2020). A "crisis situation" refers to conditions resulting from the development of certain unfavorable phenomena. The goal is to neutralize the risk and, at the same time, to maintain the safety and well-being of those affected (Hannigan \& Hertig, 2010).

One of the many types of crises caused by economic or natural disasters is food crisis which occurs when the level of hunger and malnutrition increases rapidly at the local, national or global level. It is the result of poor development of agriculture and infrastructure, or of natural disasters such as drought (Timmer, 2010). It is affected by economic factors (e.g. increase of prices), political (e.g. tyrannical government) or demographic (population growth). Crisis and disaster management models suggest appropriate responses, which include theoretical two-dimensional schema that distinguish between the social and the individual level, and present the relations between the two (Asghar et al., 2006).The transfer of knowledge, investigation of learning processes, inquiry and reporting as well as the study of behavior patterns, including information behaviors, significantly improve crisis management and prevention (Herbane, 2014). The traditional process of disaster management consists of two phases, such as pre-disaster risk-reduction and post-disaster recovery phase. The process entails activities such as prevention, mitigation and preparedness, as well as response, recovery and rehabilitation. In the medical sector, mitigation, preparation, response and recovery are distinguished as four phases of disaster management (Kimberly, 2003). The crisis management process can be divided into stages: (a) the prodromal phase or the pre-crisis stage, when signals of a potential crisis appear, (b) the acute crisis phase, (c) the stage of a chronic crisis, when it is important to look for ways to 
solve it, and (d) the stage of solving and ending the crisis, or the post-crisis stage (Coombs, 2019; Laugé et al., 2009). Crisis management may also include the stages of individual preparedness, mitigation, recovery and response, as well as various efforts by government organizations, volunteers and local organizations (Unlu et al., 2010).

A disaster occurs when various threats combine, e.g. a natural disaster or man-made disaster, caused by human activities (such as warfare), a difficult economic, medical, technical and social situation, or a lack of resources; its negative impact will be minimized by special measures, plans, coordination, and the use of appropriate resources (Alexander, 2013). It has only negative effects. Disasters are largely defined as sudden, unforeseen events that lead to the destruction, loss or damage. Usually they are single but large-scale events with a significant impact. They cannot be addressed without external assistance and involve various stakeholders; they require mechanisms to reduce their negative effects (Shaluf et al., 2003). Among the most common disasters that affect entire communities, as well as the wider economic and geopolitical situation, are natural and environmental disasters such as typhoons, volcanic eruptions, hurricanes, floods, and fires. It should be noted that a natural disaster is a cataclysm causing enormous destruction and havoc, which leads to a catastrophic situation in which everyday life is suddenly disrupted and people become helpless victims. Such catastrophes create the need for food, shelter, medical care, and protection against climatic conditions (WHO, 2020). A catastrophe is characterized by offensive activity; it is associated with human suffering or loss of life, a significant loss of economic and material resources, with which a specific community, affected by this negative situation, is unable to cope, unable to reduce its effects (Staupe-Delgado, 2019).

An incident is defined as an event caused by human error or a technological, information, economic or political failure that is limited in time. It may result in a state of emergency, catastrophe, disaster or crisis. Emergency is a dynamic condition, changing over time, while the so-called normal state is disrupted (Stoyanov, 2017). Incident has a local, regional or national character and prompts the actions of the authorities and administration. It is possible to use the community's own resources, knowledge and experience to cope with an emergency. The risk lies in the likelihood that the incident will cause a more serious crisis later on. There are potential losses in the life, health, livelihood, and property, of a specific community or of the entire population, both in the present and in the future (Staupe-Delgado, 2019).

Social crisis (or social conflict) is related to overlapping conflicts and social tensions, and affects many people simultaneously. It contributes to changes, reorientation, and disturbs the social order (Ardelt, 1998). It results in the weakening of social ties and disorganization. It involves many phenomena: class, racial, religious, and social tensions resulting in revolts, riots, and strikes. Long-term social conflicts may have a positive impact on the social, cultural and economic situation of a community. A social crisis may strengthen one group, but it may have a negative impact on another; it may also provoke uncontrollable emotions. One type of action resulting from an intense social and political conflict is terrorism, i.e. various ideologically motivated, planned and organized actions of individuals or groups violating the existing legal order. Usually, violent actions are undertaken in order to force the state authorities and the society to act in a certain way, usually against the interests of outsiders Terrorist attacks are carried out by various means (physical violence, weapons, 
or explosives). Their intention is to create anxiety and to draw attention (UNDOC, 2020). Social conflict may also be a source of creativity, catalyzing change and innovation (De Dreu, 2010). A society's turning points are often associated with a political or economic (financial) crises.

A political crisis is a situation in which the state employs authoritarian measures in response to, a breakdown of order or a direct threat to the proper functioning of the state (McNair, 2018).

In psychology, a crisis is a reaction to a singular and extremely traumatic experience, which involves ineffective attempts to overcome difficulties, and results in abandoning previous behaviors and goals, disorganization, disordering of life cycle and negative moods or even a temporary breakdown (Brammer \& Abrego, 1981; Miller, 2011). Various types of psychological crisis might be distinguished: (a) normative crisis (maturity, developmental), consisting in emotional and behavioral changes in relation to a significant event during human development that changes their life (e.g. marriage), which are typically expected and somewhat predictable (APA, 2020), (b) an existential crisis that is related to internal antagonisms, searching for the meaning of life, negative emotions related to the functioning as an individual in the society (e.g. anxiety, fear, phobia), (c) crises resulting from an unpredictable, intense event, which may be incidental, random or situational (e.g. accidents), (d) environmental crises resulting from natural or man-made disasters or from political actions (e.g. war), or a serious economic crisis (e.g. recession), which thus, by threatening life and influencing the sense of security, cause or intensify a mental crisis (Cardona, 2011), (e) chronic crises that involve long-term, permanent exposure to stress or trauma, e.g. domestic violence, which may lead to a mental illness, withdrawal, lack of sense of agency, or passivity (Gullslett et al., 2016). All these crises affect individuals. Psychology defines crisis as (a) a breakthrough and critical moment of change, (b) an abandonment, loss, or disruption of a coping mechanism, (c) lack of self-control, affective balance disorder, a threat to the identity of an individual, (d) loss of value system (Miller, 2011; Tedrick \& Wachter Morris, 2011). The so-called crisis paradigm defines it as emotional decay, with a significant impact on affective, cognitive and behavioral responses to problems and changes. This transformation and destabilization is considered alongside the background, symptoms and effects of the crisis, and actions undertaken to overcome it: they all interact with each other as parts of an entire crisis situation (Hoff \& Morgan, 2011).

In medicine, crisis is a turning point, a breakthrough, a climax of a disease followed by a change (recovery, or deterioration and death) (Hem, 2018). A health or a public health crisis refers to a difficult or dangerous situation affecting the health care system, affecting a given community. It has a significant impact on the health of the population; it often is sudden and intense. It may result from a disease that is difficult to control, industrial processes or incorrect policy, insufficient preparedness, or an extreme event. It can refer to the massive escalation of health care spending combined with its failure (Linsk, 1993). Health risks include outbreaks of infectious diseases, unsafe food, chemical contamination, radiation effects, effects of natural disasters, conflict and war (Nelson et al., 2007). 


\section{Information behavior in crisis situation}

\subsection{Research goals}

The aim of the study, after characterizing crisis and presenting the most important related terms and concepts, was to present the state of scholarship on information behavior in crisis situations. Select publications were analyzed with the following questions in mind:

(1) What types of crisis situations are described in library and information science literature?; Does the research concern epidemics and disasters?

(2) What information behaviors are discussed in this context? Do researchers analyze the activities of searching, sharing, avoiding information or any other information activities? What aspects are highlighted? What kind of users do they research?

(3) What concepts, models, theories are referenced or created?

(4) Does the empirical analysis employed in research yield interesting results, or lead to formulating new theories?

\subsection{Methodology}

The article employed qualitative strategy (Nowell et al., 2017) and used methods of scoping literature review (Munn et al., 2018; Pham et al., 2014), and a conceptual analysis to establish the meaning of a given concept by identifying and defining the contexts in which it is classified (Furner, 2004). The scoping review method was used, which is a variant of the critical literature review and is

(...) an ideal tool to determine the scope or coverage of a body of literature on a given topic and give clear indication of the volume of literature and studies available as well as an overview (broad or detailed) of its focus (Munn et al., 2018).

Thus, the aim of scoping review, as a precursor to a systematic review, is to identify a certain scope of the research field, explain key terms, concepts, characterize the method of research conducted in a given field, as well as to identify and map key assumptions, tendencies, features and conditions relating to a given concept, detecting gaps in current knowledge (Arksey \& O’Malley, 2005; Munn et al., 2018; Rumrill et al., 2010). Additionally, the study also involved thematic content analysis applying inductive forms of reflexive analysis (Braun et al., 2019; Cisek, 2014).

In July 2020, a search was carried out in the LIST database, using the keywords and the search phrase ("information behavior" OR "information seeking" OR "information sharing") AND (crisis OR crises OR disaster). To refine the search, expanders: "apply equivalent subjects" were used. The results were narrowed down to scholarly (peer-reviewed) journals and papers published between 2001 and 2020, and to English-language publications. In the end, 81 publications matching these criteria were found.

Reports and reviews were rejected, as were publications which did not refer to any aspect of information behavior or described the issue only in general terms or mentioned crisis only as an emerging or coexisting element, e.g. in management processes. Ultimately, 56 studies explicitly characterizing human information behavior in crisis situations in relation to information science were selected for the final analysis. 
Tab. 1. Thematic categories - number of terms referring to the categories of crises and disasters in scholarship published in 2010-2020

\begin{tabular}{|c|c|c|}
\hline \multicolumn{2}{|c|}{ Categories and subcategories } & \multirow{2}{*}{$\begin{array}{c}\text { Number of terms related to category } \\
115\end{array}$} \\
\hline Category & Crisis & \\
\hline \multirow{8}{*}{ subcategories } & health crisis & 32 \\
\hline & crisis situation & 27 \\
\hline & mental and personal crisis & 23 \\
\hline & political crisis & 11 \\
\hline & domestic violence & 9 \\
\hline & social crisis & 7 \\
\hline & economic crisis & 4 \\
\hline & humanitarian & 2 \\
\hline Category & Natural disaster & 52 \\
\hline \multirow{7}{*}{ subcategories } & natural disaster & 24 \\
\hline & earthquake & 16 \\
\hline & flood & 3 \\
\hline & hurricane & 3 \\
\hline & tsunami & 2 \\
\hline & storm & 2 \\
\hline & cyclone & 2 \\
\hline Category & Incidents & 34 \\
\hline \multirow{5}{*}{ subcategories } & incidents & 18 \\
\hline & shooting & 6 \\
\hline & terroristic attack & 5 \\
\hline & emergency & 3 \\
\hline & attack & 2 \\
\hline Category & Health crisis & 32 \\
\hline \multirow{3}{*}{ subcategories } & epidemic & 14 \\
\hline & health crises & 14 \\
\hline & pandemic & 4 \\
\hline Category & Accident & 13 \\
\hline Category & Disaster & 13 \\
\hline \multirow{4}{*}{ subcategories } & fires (man-made) & 4 \\
\hline & pollution & 6 \\
\hline & climate change & 2 \\
\hline & construction disaster & 1 \\
\hline Category & Problem situation & 3 \\
\hline
\end{tabular}

To conduct a conceptual analysis the most relevant sections of the text were selected that clearly related to crisis situations, and various activities related to widely understood informational behavior were identified, according to typologies of information behavior proposed by Wilson (2013), Case and Given (2016), Savolainen (2016), Godbold (2006). According to these typologies, information behaviors are divided into information use, 
gathering and responding to information, which is divided further into searching, disseminating or avoiding information (Cisek, 2017). In addition, the research accounted for the distinction between states before, during, and after searching for information (Marcella et al., 2013) and between the different types of information activities typical for these stages. It should be noted that these theories were considered as a suggestion, rather than as a ruling principle.

Thematic analysis consisted of the following stages: (a) study of data, (b) inductive generation of codes, (c) deductive coding and theorization, if possible, according to the models considered, (d) identification of topics, (e) development of results (Braun et al., 2019). Inductively transmitted codes included types of crises, types of informational behaviors, contextual factors, theories and models of informational behavior, social and affective dimensions of these behaviors, information barriers, or information competencies.

\section{Results}

\subsection{Types of described crisis situations}

The analysis showed that researchers study information behaviors in relation to various types of crises and catastrophes. They examine multiple activities, such as obtaining information, searching for information, sharing information, and various factors determining these processes during a crisis. They also analyze the context of crisis management, actions undertaken both by individuals and entire populations or institutions responsible for responding to crises. Table 1 presents the categories of crises and their number of encodings, resulting from the analyzed texts. The total number of recognized terms in relation to the category and the name of the subcategory along with the number of mentions in the text are also given.

The crisis category includes studies concerned with health crises, with publications on epidemics of various types, such as HIV/AIDS (Kanyengo, 2010), highly pathogenic avian influenza (Keselman et al., 2010), foot-and-mouth disease (Hagar, 2010b) or enterohemorrhagic Escherichia coli, EHEC (van Velsen et al., 2012). The articles in the health crisis category discussed various aspects of such a crisis, as well as information behavior of individuals while seeking information, or of systems managing the crisis (Aedo et al., 2010). The vast majority of publications analyzed considered many different crises, such as threats to life (Lê, 2014), the closure of the Google Lively communication platform (Huvila, 2015), isolation (Hagar, 2010a), as well as long-term effects of terrorist attacks in Manchester (Mirbabaie \& Marx, 2019); crises were also considered as a condition of the process of searching information (Eftekhar et al., 2019). This category also included publications on dispute or conflict situations discussed, for example, in relation to information dissemination involved in collaborative research projects (Palmer et al., 2007). The crisis category also includes studies on mental and personal crises, which may concern information behavior of victims of domestic violence or the effects of participating in various crisis situations, such as accidents, e.g. sinking of the Sewol ferry (Hong et al., 2018; Lee \& Kang, 2018) or different college shooting (Heverin \& Zach, 2011). In addition, information behavior was analyzed in relation to political, social, and economic crises, domestic violence, and 
unemployment (Webber \& Zhu, 2007) migration (Bronstein, 2017), humanitarian crisis, as well as conflict. Common information processes in crisis situations include, obtaining information in the event of a natural disaster, such as an earthquake, hurricane, storm, natural bushfire, tsunami, flood (e.g. Dabner, 2012; Kim, 2014; Shankar, 2008). The publications also considered incidents, such as arson, shootings, accidents on an oil platform, or the sinking of a ferry. The authors took into account political and social crises, analyzing the effect of riots or terrorist attacks on information behavior. The articles also included the analysis of information behavior of soldiers during military training (Sonnenwald, 2006). The research covered the dissemination and retrieval of information in the event of an explosion (Mirbabaie \& Marx, 2019). Non-natural disasters, such as construction and industrial disasters, were not widely discussed. Only a single study of the destruction of the Yakushima nuclear power plant following a tsunami considered the impact of this disaster on later information behavior (Rahmi et al., 2018). Similarly, there were no studies on the impact of transport disasters, such as air crashes.

\subsection{Types of information behavior under consideration}

Firstly, the attention should be paid to the heterogeneity and imprecision of the terminology used to describe informational behavior. Many authors inaccurately defined various behaviors. They speak of information milling, intensification, processing, creating, capturing, promoting, and even of an information explosion (Cao et al., 2013). This may be caused by the unique qualities of information behavior in crisis situations: it is often uncoordinated, extremely intense, avalanche, chaotic, ambiguous and charged with strong, negative emotions. The publications were analyzed according to the typologies described in the section on methodology. The number of terms selected during encoding is given in Table 2 .

The analysis showed that information use was the most often studied type of behavior. This category were divided into sub-categories, according to the adopted typology and relating to the categorization of such information behavior. The classification included: (a) broadly understood information use, including analysis, assessment, verification, updating, sense-making or recognition, (b) information sharing, (c) information dissemination, (d) information exchange, (e) information transfer, and (f) information responding.

The study shows that gathering was also the information behavior studied very often in relation to crisis situations. Various types of information behavior were distinguished according to the typology presented above, and ranked according to the frequency with which they were discussed in the sample: (a) information seeking, (b) information gathering, (c) information searching, (d) information overload, and (e) information browsing. Research often concerned generally understood information behavior, including mediation, organization or avoiding information, as well as cooperation. Scholars analyzed information behavior in a crisis from the perspective of information or knowledge management study, focusing on observation, analysis and evaluation of the effectiveness of emergency management systems (e.g. Etti at al., 2010). Information needs that arise in a crisis or in a disaster were also studied (e.g. Kavanaugh et al., 2017; Rahmi et al., 2018; Westbrook, 2008). 
Tab. 2. Thematic categories - number of terms referring to information behavior studied in the data sample from 2010-2020

\begin{tabular}{|l|l|c|}
\hline \multicolumn{2}{|l|}{ Categories } & Number of terms related to category \\
\hline Category & information use & 142 \\
\hline \multirow{4}{*}{ subcategories } & information use & 47 \\
\cline { 2 - 3 } & information sharing & 35 \\
\cline { 2 - 3 } & information dissemination & 21 \\
\cline { 2 - 3 } & information exchange & 17 \\
\cline { 2 - 3 } & information transfer & 11 \\
\cline { 2 - 3 } Category & information responding & 11 \\
\hline \multirow{5}{*}{ subcategories } & information gathering & 85 \\
\cline { 2 - 3 } & information seeking & 45 \\
\cline { 2 - 3 } & information gathering & 25 \\
\cline { 2 - 3 } & information searching & 14 \\
\cline { 2 - 3 } & information browsing & 1 \\
\hline \multirow{5}{*}{ Category } & information behavior & 40 \\
\cline { 2 - 3 } & information management & 32 \\
\cline { 2 - 3 } & information needs & 15 \\
\cline { 2 - 3 } & knowledge management & 8 \\
\cline { 2 - 3 } & information barriers & 1 \\
\hline
\end{tabular}

\subsection{Aspects and contexts of informational behavior examined}

The authors focused on the social and affective dimensions of information behaviors, the role of community, social and collective solidarity (Hong et al., 2018), the theory of social amplification of risk framework (Silver \& Matthews, 2016), or the formation of information grounds in crisis situations (Bronstein, 2017; Pang et al., 2019). They analyzed the concept of common grounds, comprising common and conscious information, knowledge, and group beliefs, that are the foundation for information sharing (Sonnenwald, 2006); they also studied collaborative information behavior (Lee \& Kang, 2018), transforming information worlds through dynamic processes of obtaining and using information. Scholars also discussed negative emotions, fear, uncertainty interfering with informational behavior. The affective response to risk has been examined in relation to information gathering (Choo \& Nadarajah, 2014). The articles emphasized methods, efficiency and utility of social media, especially Facebook and Twitter, as well as the relation between microblogging and information gathering and dissemination, or exchange (e.g. Dabner, 2012; Heverin \& Zach, 2011; Kim, 2014). They certainly foster communication and dissemination of information among people. The context of social media use and information behavior was considered through the lens of social amplification of risk (Silver \& Matthews, 2016). Scholars referred to this concept in order to understand how institutional structures, various information 
processes, the behavior of entire social groups and individual reactions shaped the social experience of risk and information flow. It is worth noting that

(...) theoretical framework allows for the conceptualizing of risk as dynamic, constantly evolving, and reciprocal - in that risk information can influence perceptions, which can in turn influence the dissemination and consumption of risk information (Silver \& Matthews, 2016, 2).

Research on compassion and community building following the catastrophe discussed affective responses to information and collective resilience. These activities and reactions support adaptation processes following a crisis or catastrophe, allowing persons, groups of people (or society) and organizations to experience the benefits of a catastrophe, as a result of sharing the affective response with the rest of the community (Hong et al., 2018). The scholars attended to various information sources, their availability, credibility and reliability, speed of access, lack of information, delay in delivering information and uncertainty, communication channels, information sufficiency (e.g. Choo \& Nadarajah, 2014). The processes of obtaining information were analyzed, for example, in the context of epistemic trust in information gathering and use, and in relation the role and influence of expert and individual knowledge, belief, acceptance, verification and justification of information. The impact of the epistemic trust of individuals in crisis on their information seeking behavior was analyzed, with a focus on the role of professionals and government (Hagar, 2010b). It should mention the concept of crisis informatics, i.e. a multidisciplinary field combining computing and social science to study disasters. It enables assessment of mutual relations between people, organizations, information and technology. The research concerned the importance of individual elements of crisis informatics to the methods of transferring and disseminating information in crisis, especially during technical failures affecting available systems, equipment and procedures employed in responses to crisis (Dabner, 2012; Fu, 2011; Lopatovska \& Smiley, 2014). Information behavior in crisis was also studied in relation to critical factors, critical crisis communication, as well as the issue of weak problem solving and critical incidents in research process (Palmer et al., 2007), the role of effective task implementation, and problem (Ibrahim \& Allen, 2012). The scholars also considered searching for meaning and also significance of a crisis situation, information transmission during disasters and the role of social cues and understanding environmental signals (Pang et al., 2019), as well as the role of information competences, necessary to obtain information, the need for their development, overload and disinformation was analyzed. The research also considered the context of the information overload, resulting from the proliferation of means of obtaining information and of formal and informal channels and sources (Lopatovska \& Smiley, 2014). It also analyzed information sufficiency while seeking and using information, as well as information-intensive creation in relation to transformation of information needs in dynamically changing conditions, especially during unfolding disasters situation, such as bushfires (Choo, 2013). The chances for eliminating information overload were assessed, especially in situations requiring quick provision of relevant and reliable information to support the processes of crisis management, e.g., in the case of foot-and-mouth epidemic (Hagar, 2010b). Scholars also considered the situational theory of publics, following which they analyzed various social groups, focusing on problem awareness and the range of activities related to eliminating crises. Thus, they studied the methods of collecting and processing information related to a crisis situation 
(Aldoory et al., 2010). Westbrook's series of publications on information behavior of victims of domestic violence is noteworthy. The author has studied the processes of obtaining information at different stages of crisis. Each stage, i.e. awareness of the crisis, recovery from it, fleeing and living after leaving the offender was mapped onto the crisis of domestic violence (Westbrook, 2008). Other scholars focused on the role of libraries in supporting information behavior through sharing information, anonymity, assistance in obtaining information, searching for information and collaboration with local authorities, as well as implementation and development of joint social programs (Westbrook \& Gonzalez, 2011). Single studies concerned evaluation of information processes of police departments, the quality of information provided by government services (as key information gatekeepers) and obtaining information from victims of violence by quickly responding to their information needs and creating reliable sources of information (Westbrook, 2008a).

\subsection{Types of users studied}

The research concerned various types of users in crisis situations. Different types of users were the focus in different analyzes, concerned with different information behaviors. The most common research objects were entire communities, e.g. residents, entire populations (Rahmi et al., 2018). Information behaviors occurring in organizations affecting entire crisis management systems, or the response of emergency services in the event of a disaster, e.g. by implementing action charts, were also studied (Aydin, 2016). The analyzes concerned online users, especially Twitter users who disseminate information during crises, as well as participants on forums launched for families of victims of Sewol ferry disaster (Hong et al., 2018) and microbloggers (Heverin \& Zach, 2011). Many scholars studies victims of domestic violence, accident victims, students, employees, emergency workers, experts and professionals, including information professionals and librarians (Turoff \& Hiltz, 2008), as well as autoethnographic researchers who themselves experienced natural disasters, such as Hurricane Sandy (Lopatovska \& Smiley, 2014) or became a parent and encountered crisis situations, for example related to lactation (Montesi \& Bornstein, 2017). Other participants included immigrants, domestic help, social workers, soldiers, farmers, and the elderly.

\subsection{Concepts, models, theories - referenced}

In their research, scholars most often referred to Savolainen's Everyday Life Information Seeking model and Dervin's sense-making concept to describe informational behaviors during nonroutine situations such as crises; they account for information gathering and information needs in everyday life, e.g. during a personal crisis (Westbrook, 2008). Research stressed time determinants, especially in relation to chaos, rapidity and urgency of crisis situations (Pang, 2014; Ryan, 2018). It has been shown that they have a significant impact on cognition, the processes of searching for and making sense of a troubling phenomena and situations and on activities undertaken in a crisis situation (Heverin \& Zach, 2011). Active information seeking allows information users to understand crisis situations; it becomes a kind of problem-solving (Westbrook, 2009). A crisis disrupts the individual's sense-making processes, which makes exchanging and sharing information crucial (Heverin \& Zach, 2011). Information seeking stems from a need to make sense of the crisis or disaster. The 
desire for relationships with others in a community experiencing or a crisis situation is also a part of the process of searching for meaning. As in the case of information sharing, which is critical to sense-making process following a crisis, which triggers informational behaviors, individuals strive to cooperate and be a part of a larger community (Haverin \& Zach, 2011). Eliminating uncertainty through gathering information and interacting with others is critical to sense-making during crises (Mirbabaie \& Marx, 2019). The mutability of a crisis situation also prompts sense-breaking processes, which occur when a sense-making process is disrupted by contradictory evidence or information, preventing the individual from interpreting the situation. The sense-breaking results in the rejection of inconsistencies and allows for a reconstruction of reality. Often, this phenomenon is the first response to a disaster or accident (Mirbabaie \& Marx, 2019). Scholars applied Ranganathan's model to analyze crisis management systems, which includes personality (stakeholders), matter (natural disaster), energy (stages of preparedness, response, and recovery), space (location, like hospital, epicenter or a house), and time (temporality of disaster management or time of disaster) (Yang \& Wu, 2019). Studies of information behavior of the community with reference to concepts of information worlds, small world and information grounds also focused on the social aspect of the response to a crisis and the possible cooperation (Burnett, 2015; Fisher \& Naumer, 2006). The scholars also analyzed social factors, the role of emotions and norms influencing the processes of obtaining and disseminating information, which determine information behaviors of small groups in crisis, e.g. social isolation and information poverty (Bronstein, 2017), as well as among the elderly (Pang et al., 2019). The nature of social relations in collaborative information behaviors in crisis situations was analyzed with reference to information bonding and bridging concepts. Social information bonding refers to building social and emotional relationships, creating strong bonds in small groups, which improves their responses to crisis, as they carry out information processes to fulfil their information needs. Information bridging refers to the efficient use of information, which facilitates separating nonredundant sources of information and accessing heterogeneous information (Cao et al., 2013). Scholars referred to the activity theory to analyze the relation between informational behaviors, information worlds, and information processes undertaken in them to assess and understand negative phenomena and group activity. According to the theory, people and the information processes they carry out are a part of their own and shared information worlds found during a crisis, creating a community that interprets the phenomenon and reacts to it. People act collectively, although at the same time. any single member of the community may engage in various information processes and adapt to the emerging crisis situation. A network of dependencies and activities emerges, shaped by rules and cultural norms (Pang et al., 2019). Scholars referred to the theory of Allen's person-in-progressive-situation (Allen, 1997) to discuss domestic violence, taking into account the interactions between personal limitations (e.g. limited knowledge), information needs, and limitations particular to a specific situation, such as a personal crisis (Westbrook, 2008). The research also used Johnson's comprehensive model of information seeking, comprising three categories of variables: antecedents, information carrier factors and information seeking actions. The model explains why people become information seekers, and characterizes their method of obtaining and retrieving information. The model prioritizes the knowledge regarding information needs, individual beliefs and coping mechanisms (Pang et al., 2019). 


\subsection{Concepts developed and research results}

Analysis of results indicated that information use and information gathering remain the central aspects of information behavior in crisis situations. Researchers discussed many activities common in such an incidental, chaotic and often dangerous context. They vary not only in terms of the responses, which may be active or passive, but also change with the type of crisis situation (Ryan, 2018) and depend on the conscious, competent recognition of the conditions of the information behavior. In addition, the gradual nature of crises and disasters and their intensity affect the heterogeneity of information behavior. The socio-affective and cognitive dimensions of these activities become crucial, as does the general context of the crisis situation. Table 3 presents the most important terms that emerged during coding, referring to the most important types of information behavior researched in the analyzed publications.

Tab. 3. Thematic categories - number of terms referring to information behavior in the selected publications from 2010-2020

\begin{tabular}{|c|c|c|}
\hline \multicolumn{2}{|r|}{ Categories } & \multirow{2}{*}{$\begin{array}{c}\text { Number of terms related to category } \\
246\end{array}$} \\
\hline Category & information use & \\
\hline \multirow{8}{*}{ subcategories } & information use & 106 \\
\hline & information sharing & 42 \\
\hline & information dissemination & 36 \\
\hline & information exchange & 20 \\
\hline & reaction to information & 18 \\
\hline & information provision & 10 \\
\hline & information transfer & 10 \\
\hline & information flow & 4 \\
\hline Category & information behavior & 132 \\
\hline Category & information gathering & 96 \\
\hline \multirow{4}{*}{ subcategories } & information gathering & 29 \\
\hline & information seeking & 49 \\
\hline & information browsing & 1 \\
\hline & information searching & 17 \\
\hline \multirow{10}{*}{ Category } & social dimension & 83 \\
\hline & information resources & 46 \\
\hline & crisis \& information management & 45 \\
\hline & affective dimension & 40 \\
\hline & information needs & 32 \\
\hline & cognitive dimension & 28 \\
\hline & variables (different context) & 25 \\
\hline & Communication & 22 \\
\hline & information competences & 17 \\
\hline & information barriers & 2 \\
\hline
\end{tabular}




\subsection{Information behavior in crisis models}

The research showed that there is a need for a model of crisis information behavior, especially information seeking. This is necessary due to the temporal nature of crises and the instability of the conditions during the various stages of a crisis situation, from being aware of the danger to seeking shelter or help, and finding a safe place (Rahmi et al., 2018). Each stage of a crisis, preparing, responding and recovering (Pang et al., 2019) or warning, impact, inventory, survival, recovery (Lopatovska \& Smiley, 2014), prompts specific information use and seeking processes, and gives rise to specific information needs (e.g. Choo \& Nadarajah, 2014; Lopatovska \& Smiley, 2014). An important framework for the analysis of everyday information behavior was proposed by Westbrook in relation to domestic violence. Westbrook identified attributes of information experiences, including needs, affective states, cognitive mastery, and available resources, and selected specific information needs, which emerge at four so-called turning points. These components determine the active information processes at the stages of perpetrator abandonment, post-abandon survival and long-term abandonment survival (Westbrook, 2008). Social media influence the patterns of obtaining and using information. Many scholars studied how Web environments and social media (like Facebook, Twitter, microblogs) are used as tools for information behavior in response to a crisis or a natural disaster, among them Heverin and Zach (2011), Lopatovska and Smiley (2014), Dabner (2012). However, faceto-face communication is more common and preferable, especially in the first phase of the crisis (e.g. Rahmi et al., 2018). A crisis situation, as a trigger of various information behaviors, allows an individual to understand a damaged inner world image and to repair it. Hence, the authors pay particular attention to cognitive sense-making processes. These are crucial, as through information sharing, information negotiation, and information seeking they make cooperation and understanding of the situation possible, as well as create certain benefits (social, emotional, organizational) (e.g. Heverin \& Zach, 2011; Hong et al., 2018). In crises, especially in the initial stages, marked by intensity, chaos, emotions, the processes of sense-making, sense-giving and sense-breaking are essential. They allow the individuals to cope with the loss of a safe, rational and orderly world. Sense-breaking in particular has been recognized as a driving force for re-meaning; it involves incident reporting, crisis support efforts, as well as misinformation and fake news (Mirbabaie \& Marx, 2019). Sharing information is the dominant activity in the first stages of crisis; it intensifies in the recovery stage (Heverin \& Zach, 2011). There is an urgent need for collective sense-making, determining the interpretation of events, information exchange, active creation and dissemination of information with the intent to influence the process of sense-making of other individuals (Mirbabaie \& Marx, 2019). Pang drew attention to varied styles of coping with a crisis situation when analyzing information behavior in relation to urban pollution and noticed that they are a significant variables, related to experience, age, beliefs, and information competences, i.e. the ability to effectively seek information in main information resources, social media, personal networks or from healthcare professionals (Pang, 2014). Affective and social determinants have a significant impact on various activities related to information use and gathering. Strong emotions, relationships with family, friends, neighbors and other participants of crises support the creation of information worlds or information grounds (e.g. Bronstein, 2017; Pang et al., 
2019). In these environments, people actively seek relevant, reliable, up-to-date information, or seek emotional support and confirmation of their own beliefs, share information (e.g. Hong et al., 2018; Lee \& Kang, 2018). The study conducted by Aldoory, Kim and Tindall in reference to the situational theory of publics, made it possible to recognize the nature of the common experience of victims, which may influence the processes of problem recognition and obtaining related information. In their opinion, information behavior is also influenced by media messages that intensify (even emotionally) the problem. The importance of early warning messages to raise awareness, particularly for the public health officials, was stressed (Aldoory et al., 2010). On the other hand, Ryan claims that the model of communicating risk regarding natural hazards shows that following the first alert, individuals seek confirmation to understand their situation. When a disaster occurs, people feel a sense of "shared responsibility" (Ryan, 2018). In turn, Choo and Nadarajah, bringing together the concept of crisis informatics (Hagar, 2010a) and the information seeking in risk model (Griffin et al., 2008), focused on factors such as information sufficiency, perceived information, gathering capacity, relevant information resources and beliefs, and their impact on information seeking and gathering, which rely on routine and nonroutine communication channels (Choo \& Nadarajah, 2014). The processes of sharing information about risks and information behavior in general are affected by social factors, i.e. subjective norms related to information seeking and social definitions of crisis; the affective response to risk is also determined by individual's unique characteristics (Choo \& Nadarajah, 2014). Information behavior is also analyzed in relation to crisis management systems. For example, in their analysis of the emergency management model, Kurian and John (2017) identified various phases of the crisis, such as mitigation, proper planning, recovery phases, as well as various activities typical for these stages. They also drew distinctions between the processes and users of such systems (often victims of disasters), and between the dissemination of information by active participants and the acquisition of information by the passive participants. In their opinion, it is necessary to test alert systems, verify information, accept social media (Facebook) and include the content published on the websites of crisis management agencies in the collective action system (Kurian \& John, 2017). Fan et al. (2019) discussed the joint effects of informational and task attributes of network embeddedness on collaborative emergency management capacity. The study confirmed the positive impact of workflow integration on collaborative and absorptive capability in emergency management, which supports information management at the organization level, through network embeddedness and organizational learning into crease the efficiency of the information flow. McNaughton and Rao (2018) studied to the role of effective management in the socio-technical system of crisis response, the role of ICT in crisis communication, and improvement of insufficient reporting methods; they also discussed the potential of combining the knowledge framework with Ostrom's Institutional Analysis and Development Framework strategy for information management during crises. To improve crisis management systems, Yang and Wu (2019) developed a seven-level earthquake disaster response and recovery model based on an analysis of information processes occurring during the earthquake. The framework shows how to manage and share knowledge by crossing complex boundaries in technical systems in risk management. 


\section{Conclusions and limitations}

This study is a first step towards a descriptive, conceptual analysis of the current state of scholarship on information behavior in crisis situations. It has already made contributions to the research on information behavior. Firstly, it has gathered existing definitions and typologies of crisis situations, creating a compendium of knowledge, a collection of terminology for future research. Secondly, it provided insight into research on information behavior in crisis. Combined, the scholars' discussions, characterizations, and models present a comprehensive picture of information behavior in crisis response and management. Information behavior in crisis, often occurring under the pressure of time involves evaluation of, and immediate reaction to existing circumstances. The studies showed that new forms of communication and social media have become a key element of cognitive processes and knowledge creation. They may act as triggers or inhibitors; they also influence multiple social relations. These factors affect information gathering and use, as well as other activities, e.g. information avoidance, information manipulation; they also change the role of serendipity in gathering information. Not enough attention has been paid to information barriers that may arise in crises, as well as to the changes of information needs. More scholars should consider the affective and social dimension of information behavior in a crisis situation. As Aldoory, Kim and Tindall (2010) note, shared perception of a situation, cooperation, and shared emotions are the essence of man in a crisis situations. The long-term effects of disasters and their impact on the subsequent skill development should be studied further, with particular attention paid to the changes in information behavior between repeated crises. This paper made clear the absence of research on transport disasters (airplane crashes or car crashes), which are becoming increasingly frequent, wars and armed conflicts, crimes and terrorism, as well as on crisis situations associated with migrations, and diseases (cancer or any chronic illnesses) or death. Similarly, there has not been enough research on information behavior during economic crises. The analysis presented in the article is a foundation for further research of different information activities in crisis situations of different types. More research is needed. This paper discussed only select articles, providing a basis for further research. The literature review might be expanded by analysis of related scholarship produced in other disciplines in social sciences.

\section{References}

Aedo, I., Díaz, P., Carroll, J. M., Convertino, G., Rosson, M. B. (2010). End-User Oriented Strategies to Facilitate Multi-Organizational Adoption of Emergency Management Information Systems. Information Processing \& Management, 46(1), 11-21, https://doi:10.1016/j.ipm.2009.07.002

Aldoory, L., Kim, J.-N., Tindall, N. (2010). The Influence of Perceived Shared Risk in Crisis Communication: Elaborating the Situational Theory of Publics. Public Relations Review, 36(2), 134-140, https://doi:10.1016/j.pubrev.2009.12.002

Alexander, D. E. (2013). Resilience and Disaster Risk Reduction: An Etymological Journey. Natural Hazards and Earth System Sciences, 13(11), 2707-2716, https://doi:10.5194/nhess-13-2707-2013

Allen, B. (1997). Information Needs: A Person-in-Situation Approach. In: P. Vakkari, R. Savolainen \& B. Dervin (eds.), Information Seeking in Context (111-122). London: Taylor-Graham. 
Allen, D. (2011). Information Behavior and Decision Making in Time Constrained Practice: A Dual-Processing Perspective. Journal of the American Society for Information Science and Technology, 62(11), 2165-2181, https://doi.org/10.1002/asi.21601

APA (2020). Maturational Crisis [online]. APA Dictionary of Psychology [08.12.2020], https://dictionary.apa.org/maturational-crisis

Ardelt, M. (1998). Social Crisis And Individual Growth: The Long-Term Effects of the Great. Depression Journal of Aging Studies, 12(3), 291-314.

Arksey, H., O'Malley, L. (2005) Scoping Studies: Towards a Methodological Framework. International Journal of Social Research Methodology, 8(1), 19-32, https://doi.org/10.1080/1364557032000119616

Asghar, S., Alahakoon D., Churilov L. (2006). A Comprehensive Conceptual Model for Disaster Management. Journal of Humanitarian Assistance [online], July, [08.12.2020], https://reliefweb.int/ sites/reliefweb.int/files/resources/2ADF93A261C7CBFFC12571B200374A9E-jha-gen-2jul06.pdf

Aydin, A. M. (2016). Complexity of the Strategic Level and Tactical Level Disaster Management Tasks: Activity System Analysis Through the Lens of Information Behaviour. Information World/ Bilgi Dunyasi, 17(2), 135-164, https://doi.org/ 10.15612/BD.2016.519

Bakker, R. M., Shepherd, D. A. (2017). Pull the Plug or Take the Plunge: Multiple Opportunities and the Speed of Venturing Decisions in the Australian Mining Industry. Academy of Management Journal, 60(1), 130-155, https://doi:10.5465/amj.2013.1165

Brammer, L. M., Abrego, P. J. (1981). Intervention Strategies for Coping with Transitions. The Counseling Psychologist, 9(2), 19-36, https://doi.org/10.1177/001100008100900203

Braun, V., Clarke, V., Hayfield, N., Terry, G. (2019). Thematic Analysis. In: P. Liamputtong (ed.), Handbook of Research Methods in Health Social Sciences (843-860). Singapore: Springer, https:// doi.org/10.1007/978-981-10-5251-4_103

Bronstein, J. (2017). Information Grounds as a Vehicle for Social Inclusion of Domestic Migrant Workers in Israel. Journal of Documentation, 73(5), 934-952, https://doi:10.1108/jd-02-2017-0023

Bundy, J., Pfarrer, M. D., Short, C. E., Coombs, W. T. (2016). Crises and Crisis Management: Integration, Interpretation, and Research Development. Journal of Management, 43(6), 1661-1692, https://doi:10.1177/0149206316680030

Burnett, G. (2015). Information Worlds and Interpretive Practices: Toward an Integration of Domains. Journal of Information Science Theory and Practice, 3(3), 6-16, https://doi: 10.1633/JISTaP.2015.3.3.1

Cao, Q., Lu, Y., Dong, D., Tang, Z., Li, Y. (2013). The Roles of Bridging and Bonding in Social Media Communities. Journal of the American Society for Information Science and Technology, 64(8), 1671-1681, https://doi:10.1002/asi.22866

Cardona, O.D. (2011) Disaster Risk and Vulnerability: Concepts and Measurement of Human and Environmental Insecurity. In: H. Brauch et al. (eds.), Coping with Global Environmental Change, Disasters and Security. Hexagon Series on Human and Environmental Security and Peace, vol. 5, (107-121). Berlin, Heidelberg: Springer, https://doi.org/10.1007/978-3-642-17776-7_3

Case, D. O., Given, L. M. (2016). Lookingfor Information. A Survey of Research on Information Seeking, Needs and Behavior. 4th edition. Bingley: Emerald Group Publishing Limited.

Choo, C. W., Nadarajah, I. (2014). Early Warning Information Seeking in the 2009 Victorian Bushfires. Journal of the Association for Information Science and Technology, 65(1), 84-97, https:// doi:10.1002/asi.22952

Cisek, S. (2017). Zachowania informacyjne. In: A. Żbikowska-Migoń, M. Skalska-Zlat (eds.), Encyklopedia ksiażki t. 2 (643-647). Wrocław: Wydawnictwo Uniwersytetu Wrocławskiego.

Cisek, S. (2014). Analiza danych jakościowych we współczesnej informatologii. In: B. Sosińska-Kalata, M. Przastek-Samokowa \& Z. Wirogórska (eds.), Nauka o informacji w okresie zmian (79-88). Warszawa: Wydawnictwo SBP. 
Combe, I. A., Rudd, J. M., Leeflang, P. S. H., Greenley, G. E. (2012). Antecedents to Strategic Flexibility. European Journal of Marketing, 46(10), 1320-1339, https://doi:10.1108/03090561211248053

Coombs, W. T. (2019). Ongoing Crisis Communication: Planning, Managing, and Responding (5th ed.). Los Angeles: Sage.

Dabner, N. (2012). "Breaking Ground" in the Use of Social Media: A Case Study of a University Earthquake Response to Inform Educational Design With Facebook. The Internet and Higher Education, 15(1), 69-78, https://doi:10.1016/j.iheduc.2011.06.001

De Dreu, C. K. W. (2010). Social Conflict: The Emergence and Consequences of Struggle and Negotiation. In: S. T. Fiske, D. T. Gilbert, G. Lindzey (eds), Handbook of Social Psychology 5th ed., vol. 2, (983-1023). Hoboken, NJ: Wiley. https://doi:10.1002/9780470561119.socpsy002027

Eftekhar, Z., Soraya, Z., Moghaddam, H.S. (2019). New Educational System and Information and Communication Technology's Influence on the Process of Information Seeking Behavior: Case of Students of Islamic Higher Education. International Journal of Information Science E Management, 17(1), 73-82.

Etti, S., Perkinton, K., Cheuk, B., Curtis, J. (2010). Growing the ERM Energy and Climate Change Practice Through Knowledge Sharing. Journal of Information E Knowledge Management, 9(3), 241-250, https://doi:10.1142/s0219649210002644

Fan, B., Liu, R., Huang, K., Zhu, Y. (2019). Embeddedness in Cross-Agency Collaboration and Emergency Management Capability: Evidence From Shanghai's Urban Contingency Plans. Government Information Quarterly, 101395, https://doi:10.1016/j.giq.2019.101395

Fisher, K. E., Julien, H. (2009). Information Behavior. Annual Review of Information Science and Technology, 43(1), 1-73, https://doi.org/10.1002/aris.2009.1440430114

Fisher, K. E., Naumer, C. M. (2006). Information Grounds: Theoretical Basis and Empirical Findings on Information Flow in Social Settings. In: A. Spink \& C. Cole (eds.), New directions in human information behavior (93-111). Berlin: Springer.

Fu, L. (2011). The Government Response to 9/11: Communications Technology and the Media. Library \& Archival Security, 24(2), 103-118, https://doi: 10.1080/01960075.2011.592034

Furner, J. (2004). Conceptual Analysis: A Method for Understanding Information as Evidence, and Evidence as Information. Archival Science, 4(3-4), 233-265, https://doi.org/10.1007/s10502-005-2594-8

Godbold, N. (2006). Beyond Information Seeking: Towards a General Model of Information Behaviour. Information Research [online], 11(4) paper 269, [08.12.2020], http://InformationR.net/ ir/11-4/paper269.html

Griffin, R., Yang, Z., Huurne, E. T., Boerner, F., Ortiz, S., Dunwoody, S. (2008). After the Flood: Anger, Attribution, and the Seeking of Information. Science Communication, 29(3), 285-315, https://doi. org/10.1177/1075547007312309

Gullslett, M. K., Kim, H. S., Andersen, A. J. W., Borg, M. (2016). "Emotional Darkness Without Solutions": Subjective Experiences of Mental Health Crisis. International Journal of Mental Health, 45(3), 161-170, https://doi:10.1080/00207411.2016.1185875

Gundel, S. (2005). Towards a New Typology of Crises. Journal of Contingencies and Crisis Management, 13(3), 106-115, https://doi:10.1111/j.1468-5973.2005.00465.x

Hagar, C. (2010a). Introduction to Crisis Informatics. Bulletin of the American Society for Information Science and Technology, 36(5), 10-12, https://doi: 10.5771/0943-7444-2019-2-77

Hagar, C. (2010b). Whom Do You Trust? Information Seeking During the U.K. Foot and Mouth Crisis. Library \& Archival Security, 23(1), 3-18, https://doi:10.1080/01960070903200417

Hannigan, M. A., Hertig, C. A. (2010). Crisis Intervention. In: S. J. Davies (ed). The Professional Protection Officer. Practical Security Strategies and Emerging Trends. (295-303). Burlington: Elsevier, Butterworth-Heinemann, https://doi.org/10.1016/B978-1-85617-746-7.00025-0

Hem, E. (2018). Den Medisinske Krise. Tidsskrift for den Norske laegeforening : tidsskrift for praktisk medicin, ny raekke, 138(1), https://doi.org/10.4045/tidsskr.17.0401 
Herbane, B. (2014). Information Value Distance and Crisis Management Planning. SAGE Open, 4(2), https://doi.org/10.1177/2158244014532929

Heverin, T., Zach, L. (2011). Use of Microblogging for Collective Sense-Making During Violent Crises: A Study of Three Campus Shootings. Journal of the American Society for Information Science and Technology, 63(1), 34-47, https://doi:10.1002/asi.21685

Hoff, L. A., Morgan, B. D. (2011). Psychiatric and Mental Health Essentials in Primary Care. London, New York: Routledge.

Hong, J. Y. J, Kim, N., Lee, S., Kim, J. H. (2018). Community Disaster Resilience and Social Solidarity on Social Media: A Semantic Network Analysis on the Sewol Ferry Disaster Information Research [online], 23(3), paper 798, [08.12.2020], http://InformationR.net/ir/23-3/paper798.html

Huvila, I. (2015). "We've Got a Better Situation": The Life and Afterlife of Virtual Communities in Google Lively. Journal of Documentation, 71(3), 526-549, https://doi:10.1108/ jd-09-2013-0116

Ibrahim, H. N., Allen, D. (2012). Information Sharing and Trust During Major Incidents: Findings From the Oil Industry. Journal of the American Society for Information Science and Technology, 63(10), 1916-1928, https://doi:10.1002/asi.22676

Kanyengo, C. W. (2010). Information and Communication: A Library's Local Response to HIV/ Aids in Zambia. Health Information \& Libraries Journal, 27(1), 57-65, https://doi:10.1111/j.1471$-1842.2009 .00855 . x$

Kavanaugh, A., Sheetz, S. D., Skandrani, H., Fox, E. A. (2017). Media Use by Young Tunisians During the 2011 Revolution vs 2014 Elections. Information Polity, 22(2-3), 137-158, https://doi:10.3233/ ip-170412

Kellens, W., Zaalberg, R., De Maeyer, P. (2011). The Informed Society: An Analysis of the Public's Information-Seeking Behavior Regarding Coastal Flood Risks. Risk Analysis, 32(8), 1369-1381, https://doi:10.1111/j.1539-6924.2011.01743.x

Keown-McMullan, C. (1997). Crisis: When Does a Molehill Become a Mountain?. Disaster Prevention and Management: An International Journal, 6(1), 4-10, http://dx.doi.org/10.1108/09653569710162406

Keselman, A., Rosemblat, G., Kilicoglu, H., Fiszman, M., Jin, H., Shin, D., Rindflesch, T. C. (2010). Adapting Semantic Natural Language Processing Technology to Address Information Overload in Influenza Epidemic Management. Journal of the American Society for Information Science and Technology, 61(12), 2531-2543, https://doi:10.1002/asi.21414

Kim, T. (2014). Observation on Copying and Pasting Behavior During the Tohoku Earthquake: Retweet Pattern Changes. International Journal of Information Management, 34(4), 546-555, https://doi:10.1016/j.ijinfomgt.2014.03.001

Kimberly, A. (2003). Disaster Preparedness in Virginia Hospital Centre-Arlington After Sept 11, 2001. Disaster Management Response 1(3), 80-86, https://doi.org/10.1016/S1540-2487(03)00048-8

Krakowska, M. (2016). Zachowania informacyjne człowieka. In: W. Babik (ed.), Nauka o informacji (429-455). Warszawa: Wydawnictwo SBP.

Kurian, J. C., John, B. M. (2017). User-Generated Content on the Facebook Page of an Emergency Management Agency: A Thematic Analysis. Online Information Review 41(4), 558-579, https:// doi.org/10.1108/OIR-09-2015-0295

Laugé, A., Sarriegi, J. M., Torres, J. M. (2009). The Dynamics of Crisis Lifecycle for Emergency Management [online] [08.12.2020], https://proceedings.systemdynamics.org/2009/proceed/papers/ P1112.pdf

Lê, M. L. (2014). Information Needs of Public Health Staff in a Knowledge Translation Setting in Canada. Journal of the Canadian Health Libraries Association, 34(1), 3-11, https://doi:10.5596/c13-001

Lee, J., Kang, J. H. (2018). Crying Mothers Mobilise for a Collective Action: Collaborative Information Behaviour in an Online Community. Information Research [online], 23(2), paper 792, [08.12.2020], http://InformationR.net/ir/23-2/paper792.html 
Lopatovska, I., Smiley, B (2014). Proposed Model of Information Behaviour in Crisis: The Case of Hurricane Sandy. Information Research [online], 19(1) paper 610, [08.12.2020], http://InformationR.net/ir/19-1/paper610.html

Linsk, J. A. (1993). American Medical Culture and the Health Care Crisis. American Journal of Medical Quality, 8(4), 174-180, https://doi:10.1177/0885713x9300800403

Maitland, E., Sammartino, A. (2015). Decision Making and Uncertainty: The Role of Heuristics and Experience in Assessing a Politically Hazardous Environment. Strategic Management Journal, 36(10), 1554-1578, https://doi.org/10.1002/smj.2297

Marcella, R., Pirie, T., Rowlands, H. (2013). The Information Seeking Behaviour of Oil and Gas Industry Workers in the Context of Health, Safety and Emergency Response: A Discussion of The Value of Models of Information Behaviour. Information Research [online], 18 (3), [08.12.2020], http://www.informationr.net/ir/183/paper583.html

McNair, B. (2018). An Introduction to Political Communication. New York: Routledge.

McNaughton, M., Rao, L. (2018). Governing Knowledge Commons in Caribbean Disaster Management: A Comparative Institutional Analysis. Information Services \& Use, 37(4), 437-449, https:// doi:10.3233/isu-170855

Merendino, A., Sarens, G. (2020). Crisis? What Crisis? Exploring the Cognitive Constraints on Boards of Directors in Times of Uncertainty. Journal of Business Research, 118, 415-430, https:// doi:10.1016/j.jbusres.2020.07.005

Miller, G. (2011). Fundamentals of Crisis Counseling. Hoboken, New Jersey: John Wiley \& Sons.

Mirbabaie, M., Marx, J. (2019). "Breaking" News: Uncovering Sense-Breaking Patterns in Social Media Crisis Communication During the 2017 Manchester Bombing. Behaviour E Information Technology 39(3), 1-15, https://doi:10.1080/0144929x.2019.1611924

Montesi, M., Bornstein, A. B. (2017). Defining a Theoretical Framework for Information Seeking and Parenting: Concepts and Themes From a Study With Mothers Supportive of Attachment Parenting. Journal of Documentation, 73(2), 186-209, https://doi.org/10.1108/JD-04-2016-0047

Munn, Z., Peters, M. D. J., Stern, C., Tufanaru, C., McArthur, A., Aromataris, E. (2018). Systematic Review or Scoping Review? Guidance for Authors When Choosing Between a Systematic or Scoping Review Approach. BMC Medical Research Methodology, 18(1), https://doi:10.1186/s12874-018-0611-x

Nelson, C., Lurie, N., Wasserman, J., Zakowski, S. (2007). Conceptualizing and Defining Public Health Emergency Preparedness. American Journal of Public Health, 97 (Suppl. 1), S9-S11, https://doi. org/10.2105/AJPH.2007.114496

Nowell, L. S., Norris, J. M., White, D. E., Moules, N. J. (2017). Thematic Analysis: Striving to Meet the Trustworthiness Criteria. International Journal of Qualitative Methods, 16, 1-13, https://doi. org $/ 10.1177 / 1609406917733847$

Palmer, C. L., Cragin, M. H., Hogan, T. P. (2007). Weak Information Work in Scientific Discovery. Information Processing \& Management, 43(3), 808-820, https://doi:10.1016/j.ipm.2006.06.003

Pang, N., Karanasios, S., Anwar, M. (2019). Exploring the Information Worlds of Older Persons During Disasters. Journal of the Association for Information Science and Technology 71(6), 619-631, https://doi.org/10.1002/asi.24294

Pang, N. (2014). Crisis-Based Information Seeking: Monitoring Versus Blunting in the Information Seeking Behaviour of Working Students During the Southeast Asian Haze Crisis. Information Research [online], 19(4), 171-181, [08.12.2020], http://informationr.net/ir/19-4/isic/isic14.html\#.X6RwmWhKhPY

Perry, R.W. (2007). What Is a Disaster?. In: H. Rodríguez et al. (eds.), Handbook of Disaster Research. Handbooks of Sociology and Social Research (1-15). New York, NY: Springer, https://doi. org/10.1007/978-0-387-32353-4_1

Pham, M. T., Rajić, A., Greig, J. D., Sargeant, J. M., Papadopoulos, A., McEwen, S. A. (2014). A Scoping Review of Scoping Reviews: Advancing the Approach and Enhancing the Consistency. Research Synthesis Methods, 5(4), 371-385, https://doi.org/10.1002/jrsm.1123 
Pisani, A. R., Murrie, D. C., Silverman, M. M. (2016). Reformulating Suicide Risk Formulation: From Prediction to Prevention. Academic Psychiatry: the Journal of the American Association of Directors of Psychiatric Residency Training and the Association for Academic Psychiatry, 40(4), 623-629, https://doi.org/10.1007/s40596-015-0434-6

Rahmi, R., Joho, H., Shirai, T. (2018). An Analysis of Natural Disaster-Related Information-Seeking Behavior Using Temporal Stages. Journal of the Association for Information Science and Technology 70(7), 715-728, https://doi:10.1002/asi.24155

Rumrill, P. D., Fitzgerald, S. M., Merchant, W. R. (2010). Using Scoping Literature Reviews as a Means of Understanding and Interpreting Existing Literature. Work (Reading, Mass.), 35(3), 399-404, https://doi.org/10.3233/WOR-2010-0998

Ryan, B. (2018). A Model to Explain Information Seeking Behaviour by Individuals in the Response Phase of a Disaster. Library \& Information Science Research, 40(2), 73-85. https://doi.org/10.1016/j. lisr.2018.05.001

Samdanis, M., Lee, S. H. (2019). Uncertainty, Strategic Sensemaking and Organisational Failure in the Art Market: What Went Wrong With Lvmh's Investment in Phillips Auctioneers? Journal of Business Research, 98, 475-488, https://doi.org/10.1016/j.jbusres.2018.08.030

Savolainen, R. (2005). Everyday Life Information Seeking. In: K.E. Fisher, S. Erdelez, \& L.E.F. McKechnie (eds), Theories of Information Behavior (143-148). Medford: Information Today.

Savolainen, R. (2016). Approaching the Affective Barriers to Information Seeking: The Viewpoint of Appraisal Theory. Information Research [online], 21(4), [08.09.2020], http://InformationR.net/ ir/21-4/isic/isic1603.html

Shaluf, I. M., Ahmadun, F., Mat Said, A. (2003). A Review of Disaster and Crisis. Disaster Prevention and Management: An International Journal, 12(1), 24-32, https://doi:10.1108/ 09653560310463829

Shaluf, M. I. (2007). An Overview on Disasters. Disaster Prevention and Management: An International Journal, 16(5), 687-703, https://doi:10.1108/09653560710837000

Shankar, K. (2008). Wind, Water, and Wi-Fi: New Trends in Community Informatics and Disaster Management. The Information Society, 24(2), 116-120, https://doi.org/10.1080/01972240701883963

Shaw, P. (2010) Crisis moments. In: Defining Moments (70-79). London: Palgrave Macmillan, https:// doi.org/10.1057/9780230303072_9

Silver, A., Matthews, L. (2016). The Use of Facebook for Information Seeking, Decision Support, and Self-Organization Following a Significant Disaster. Information, Communication E Society, 20(11), 1680-1697, https://doi:10.1080/1369118x.2016.1253762

Sonnenwald, D. H. (2006). Challenges in Sharing Information Effectively: Examples From Command and Control. Information Research [online], 11(4), paper 270, [08.12.2020], http://informationr. net/ir/11-4/paper270.html

Staupe-Delgado, R. (2019). Analysing Changes in Disaster Terminology Over the Last Decade. International Journal of Disaster Risk Reduction, 40, https://doi:10.1016/j.ijdrr.2019.101161

Stoyanov, S. (2017). Crisis and Disaster Management Terminology. NATO Science for Peace and Security Series C: Environmental Security, 3-10, https://doi:10.1007/978-94-024-1071-6_2

Tangjia, W. (2014). A Philosophical Analysis of the Concept of Crisis. Frontiers of Philosophy in China, 9(2), 254-267, https://doi:10.3868/s030-003-014--0021-0

Tedrick, S., Wachter Morris, C. A. (2011). Integrating Individual Psychology and Crisis Theory: An application and case study. The Journal of Individual Psychology, 67(4), 364-379.

Timmer, C. P. (2010). Preventing Food Crises Using a Food Policy Approach. The Journal of Nutrition, 140(1), 224S-228S, https://doi.org/10.3945/jn.109.110379

Turoff, M., Hiltz, S. (2008). Assessing the Health Information Needs of the Emergency Preparedness and Management Community. Information Services and Use, 28, 269-280, https://doi:10.3233/ ISU-2008-0588 
UNDOC (2020). Defining Terrorism [online]. United Nations Office on Drugs and Crime, [08.12.2020], https://www.unodc.org/e4j/en/terrorism/module-4/key-issues/defining-terrorism.html

Unlu, A., Kapucu, N., Sahin, B. (2010). Disaster and Crisis Management in Turkey: A Need for a Unified Crisis Management System. Disaster Prevention and Management, 19(2), 155-174, https:// doi:10.1108/09653561011037977

Vakkari, P. (1997). Information Seeking in Context: A Challenging Meta-Theory. In: P. Vakkari, R. Savolainen, B. Dervin, (eds.), Information Seeking in Context: Proceedings of an International Conference on Research in Information Needs, Seeking and Use in Different Contexts (451-646). London \& Los Angeles, CA: Taylor Graham.

van Velsen, L., van Gemert-Pijnen, J. E., Beaujean, D. J., Wentzel, J., van Steenbergen, J. E. (2012). Should Health Organizations Use Web 2.0 Media in Times of an Infectious Disease Crisis? An In-depth Qualitative Study of Citizens' Information Behavior During an EHEC Outbreak. Journal of Medical Internet Research 14(6): e181, 1-14, https://doi. 10.2196/jmir.2123

Webber, S., Zhu. W. (2007). Employment Information Needs of Chinese Young Adults in Sheffield. Journal of Librarianship and Information Science, 39(4), 223-233, https://doi:10.1177/0961000607083214

Westbrook, L., Gonzalez, M. E. (2011). Information Support for Survivors of Intimate Partner Violence: Public Librarianship's Role. Public Library Quarterly, 30(2), 132-157, https://doi:10.1080 /01616846.2011.575709

Westbrook, L. (2009). Crisis Information Concerns: Information Needs of Domestic Violence Survivors. Information Processing $\mathcal{E}$ Management, 45(1), 98-114, https://doi:10.1016/j.ipm.2008.05.005

Westbrook, L. (2008). Understanding Crisis Information Needs in Context: The Case of Intimate Partner Violence Survivors. The Library Quarterly, 78(3), 237-261, https://doi:10.1086/588443

Westbrook, L. (2008a). E-Government Support for People in Crisis: An Evaluation of Police Department Website Support for Domestic Violence Survivors Using "Person-in-Situation" Information Need Analysis. Library E Information Science Research, 30(1), 22-38, https://doi:10.1016/j. lisr.2007.07.004

WHO (2020). Environmental Health in Emergencies [online]. World Health Organization, [08.12.2020], https://www.who.int/environmental_health_emergencies/natural_events/en/

Wilson, T. (ed.). (2013). Theory in Information Behaviour Research. Sheffield, UK: Eiconics Ltd.

Wooten, L. P., James, E. H. (2008). Linking Crisis Management and Leadership Competencies: The Role of Human Resource Development. Advances in Developing Human Resources, 10(3), 352-379, https://doi.org/10.1177/1523422308316450

Yang, T. M., Wu, Y. J. (2014). Exploring the Determinants of Cross-Boundary Information Sharing in the Public Sector: An E-Government Case Study in Taiwan. Journal of Information Science, 40(5), 649-668, https://doi.org/10.1177/0165551514538742

Yang, L., Wu, Y. (2019). Creating a Taxonomy of Earthquake Disaster Response and Recovery for Online Earthquake Information Management. Knowledge Organization, 46(2), 77-89, https:// doi.org/10.5771/0943-7444-2019-2-77

\title{
Zachowania informacyjne w sytuacjach kryzysowych
}

\begin{abstract}
Abstrakt
Cel/Teza: Artykuł dotyczy problematyki badań nad zachowaniami informacyjnymi podczas kryzysów, konfliktów i katastrof. Zawiera teoretyczne rozważania dotyczące identyfikacji heterogenicznych aktywności informacyjnych oraz próbę zdefiniowania i charakterystyki zróżnicowanych sytuacji kryzysowych.
\end{abstract}


Koncepcja/Metody badań: Zastosowano podejście jakościowe, a także metody/techniki: krytyczny przegląd literatury określający zakres (scoping review), analizę pojęciową i analizę tematyczną. Jakościowa analiza treści dotyczyła wybranych, reprezentatywnych publikacji z lat 2001-2020.

Wyniki i wnioski: Badania zachowań informacyjnych w różnych sytuacjach kryzysowych stanowią istotny obszar badawczy nauki o informacji. Jednak eksploracje dotyczą ograniczonego pola poszukiwań, które należy rozszerzyć o wieloaspektowe zagadnienia związane z indywidualnymi i zbiorowymi zachowaniami informacyjnymi we współczesnych sytuacjach kryzysowych, a także w obliczu katastrof. Oryginalność/Wartość poznawcza: Artykuł stanowi pierwszą próbę analizy pojęciowej i koncepcyjnej zachowań informacyjnych w sytuacjach kryzysowych. Omówiono różne rodzaje kryzysów i działań informacyjnych podejmowanych w sytuacjach kryzysowych, aby stworzyć teoretyczny i praktyczny fundament dla przyszłych badań zachowań informacyjnych.

\section{Słowa kluczowe}

Analiza jakościowa. Jakościowa analiza treści. Jakościowa analiza zawartości. Katastrofa. Kryzys. Sytuacje kryzysowe. Zachowania informacyjne.

MONIKA KRAKOWSKA, PhD, is Associate Professor at the Institute of Information Studies, Faculty of Management and Social Communication, Jagiellonian University in Krakow, Poland. Her research interests include human information behavior, social and affective aspects of human information activities, qualitative information behavior research, and information culture. Selected publications: Affective Factors in Human Information Behavior: Conceptual Analysis of Interdisciplinary Research in Information Behavior (2020); The Diary Method and Analysis of Student's Mental Representations of Information Apaces as the Research Approach in Information Behavior Research (2019, co-author: S. Cisek); Qualitative Analysis of Visual Data in Information Behavior Research (2019, co-author: S. Cisek); Efektywność indywidualnego zarządzania informacją z perspektywy zachowań informacyjnych człowieka. In: W. Babik (ed). Zarządzanie informacją (2019); Diagnozowanie rozwiązań w zakresie zarządzania informacją w organizacji z perspektywy teorii information grounds i zachowań normatywnych. In: R. Sapa (ed.) Diagnostyka w zarządzaniu informacją: perspektywa informatologiczna (2017).

Contact to the Author:

monika.krakowska@uj.edu.pl

Institute of Information Studies,

Faculty of Management and Social Communication,

Jagiellonian University in Krakow,

ul. prof. Stanistawa Łojasiewicza 4,

30-348 Krakow, Poland 